\title{
Social Media in Agricultural Extension Services: Farmers and Extension Agents Perspective
}

\author{
Mithun Kumar Ghosh, Shaikh Shamim Hasan, Ummey Maria, Safayet Akon, Hossain Ali, \\ Moheuddin and Abdullah Al Noman
}

\begin{abstract}
The study aimed to assess the present status of social media in agricultural extension services as well as attitude of the farmers with their problems towards social media. The study was conducted in five unions of Chapainawabganj Sadar Upazila, Chapainawabganj district. A total of 90 respondents (60 farmers and 30 extension officers) were randomly selected from the study area. The majority of farmers $(75 \%)$ had a moderately positive view toward social media. According to the findings, all of the farmers were men, and $46.7 \%$ of them were in their middle years. The majority of the farmers $(53.3 \%)$ were illiterate, the majority $(38.3 \%)$ were small-group farmers based on land ownership, and only a small percentage $(11.7 \%)$ used social media. The most popular social media platforms among them were Facebook and YouTube. Other respondents used social media at a rate of $93.3 \%$ for extension officers. About 46.7 percent of extension staff utilized both Facebook and YouTube to communicate with farmers, while $33.3 \%$ chose Facebook over other social media. They mainly used social media for agricultural information, amusement, personal reasons, and information sharing, but they did not find the use of social media solely for agricultural purposes to improve extended services agreeable. According to the extension officers, social media can assist farmers in receiving critical information and so bridge the gap between them and farmers. Farmers' lack of usage of social media is due to major issues such as lack of awareness, illiteracy, and lack of training, according to the study. As a result, it is proposed that researchers, extension officials, and the government take appropriate initiatives to encourage farmers to use social media.
\end{abstract}

Keywords - Extension agents, extension services, farmers' attitude, problems, social media.

\section{INTRODUCTION}

"Social Media is a form of electronic communication through which users create online communities to share information, ideas, personal messages and other content" [1]. The rapid growth of 2.56 billion mobile social media users worldwide, accounting for roughly 68 percent of all internet users, demonstrates the revolutionary elements of social media [2]. Because of the rising use of Smartphones and mobile internet users around the world, social media has become a crucial form of communication [3]. Information and communication technology (ICTs) have been regarded as

Published on October 28, 2021.

M. K. Ghosh, EXIM Bank Agricultural University Bangladesh, Bangladesh.

(e-mail: mithunaer@ebaub.edu.bd)

S. S. Hasan, Bangabandhu Sheikh Mujibur Rahman Agricultural

University, Bangladesh.

(corresponding e-mail: shamim.aer@bsmrau.edu.bd)

U. Maria, EXIM Bank Agricultural University Bangladesh, Bangladesh.

(e-mail: kibtia.tusti@gmail.com)

S. Akon, EXIM Bank Agricultural University Bangladesh, Bangladesh. a key development instrument for up-scaling the economic and social standing of Bangladeshi residents as part of a parliamentary election promise dubbed "Digital Bangladesh." [4].

Agriculture extension has a long history in Bangladesh, dating back to the nineteenth century. With the introduction of contemporary technology in agriculture, the job of extension services has become increasingly vital. The current agricultural extension service organization was modified in the early 1980s with the goal of motivating and assisting farmers in adopting new production practices in order to raise their output, meet national consumption requirements, maximize exports, and minimize imports. Its goal was to provide farmers with the most up-to-date research and farming techniques in order to boost their output. The Department of Agriculture Extension (DAE) is the Ministry of Agriculture's frontier department, responsible for providing farmers with extension services. However, when compared to the number of farmers in our country, there are significantly fewer extension personnel [5]. Farmers' operating environments are evolving, which implies agricultural extension agencies must adjust their services and delivery methods. Farm visits, discussion groups, office and phone consultations, and training courses were all examples of traditional advisory methods [6]. According to [7], the function of advisory services in knowledge transfer is evolving in a larger context where knowledge is contested rather than simply passed from advisers to farmers. This void must be filled by looking into different agricultural extension service delivery possibilities. ICTs can make agricultural extension information more accessible, faster, and more accurate [8]-[10].

So, organizations all over the world are progressively using social media platforms like Twitter, Facebook, and YouTube. Marketing, law enforcement, and crisis management are some of the sectors where these applications are being used. e.g., [11]-[14]. Both researchers and practitioners in the field of agricultural extension are interested in social media. e.g., [15], [16]. Facebook, Twitter, YouTube, and Blog are among the applications that have been suggested as having potential for extension efforts [17], [18]. Numerous benefits that these applications could provide to the field, including real-time

(e-mail: safayetsf@ gmail.com)

H. Ali, EXIM Bank Agricultural University Bangladesh, Bangladesh.

(e-mail: hossainali55720@gmail.com)

Moheuddin, EXIM Bank Agricultural University Bangladesh, Bangladesh.

(e-mail: rakibmoheuddin220@gmail.com)

A. Al Noman, EXIM Bank Agricultural University Bangladesh,

Bangladesh.

(e-mail: alnoman.0122@gmail.com) 
interaction with target groups, mobile access to extension materials, and outreach to new audiences [19].

According to research, the public spends $22 \%$ of their time on social media sites, demonstrating just how popular they have grown [20]. Globally, an estimated 2.65 billion people used social media in 2018 , with that number expected to rise to nearly 3.1 billion by 2021 . Worldwide, social network penetration is steadily expanding, with 45 percent in January 2019 [21]. Bangladesh has around 30 million active social media users. The percentage of people who use social media is $18 \%$. (30.5 million). The percentage of mobile connections is at $83 \%$ (137.2 million). $74 \%$ of social media users identify as male, while 26 percent identify as female [22].

Furthermore, social media's rapid expansion has the potential to be used as a learning resource and a source of agricultural information to help farmers handle challenges in the field. According to [23], the competence extension based on community assessment is influenced by the media consumption element. The more frequently extension services employ media, the more knowledge they gain and the better chance they have of solving agricultural concerns. Additionally, through social media, some people can exchange ideas, work together, and collaborate to produce artwork, sights, and arguments, as well as discover wonderful companions or partners and develop a community [24].

Moreover, in the previous decade, ICT-based extension delivery systems have grown as an innovative extension delivery system with convergence-based farmer-friendly diversified crop, enterprise-specific, and market-led extension delivery systems all over the world. In agriculture extension, social media saves money, time, and effort. Social media provides a wealth of information while also being engaging. When compared to typical extension methods, the cost per unit is lower. Direct communication with experts is possible. Appropriate for increasing user awareness. Extension knowledge to a national audience [25].

However, social media in agricultural extension is still relatively young, and its promise has yet to be realized. This paper addresses the core research question: what is the present status of social media use among the different stakeholders like farmers and extension agents? The following objectives were formulated to answer the question.

- To determine the present status and problems of social media use by the farmers and extension personnel, and

- To ascertain the attitude of respondents towards social media.

\section{MATERIALS AND METHODS}

\section{A. Study Area}

The study was conducted in Chapainawabganj Sadar Upazila (lower administrative unit) of Chapainawabganj district in Rajshahi division. Chapainawabganj is situated between the latitude $24^{\prime} 22$ to $24^{\prime} 57$ and longitude $87^{\prime} 23$ to 88 '23. The district comprises of five Upazilas namely Chapainawabganj Sadar, Bholahat, Shibganj, Gomastapur and Nachole. Chapai Nawabganj Sadar Upazila is divided into Nawabganj Municipality and 14 union parishads. The Upazila covers $451,8 \mathrm{~km} 2$ with 530,592 people. Out of 14 unions of Chapainawabganj Sadar upazila 5 unions were selected randomly for data collection. The unions were Paurashava, Baragharia, Baliadanga, Gobratala and Jhilim.

\section{B. Data Collection Procedure and Analysis}

This study adopted a descriptive survey research and the primary data collection tools were pre-structured questionnaire which involved in-depth interviews from 02 types of respondents. The respondents were the extension agents and the farmers. A total number of 60 farmers were randomly selected from the five unions (12 farmers from each union) and 30 extension agents. We chose specifically the Sub Assistant Agricultural Officers (SAAOs) under the department of Agricultural Extension (DAE) from the Sadar upazila. The SAAOs are the root level agricultural extension service providers of Bangladesh, and they have close contacts with the farmers. After initial arbitrary selection, extensive field visits and data collection were conducted between October to December 2019. These visits were conducted to interview and explain the concept of social media use in agriculture. For the researchers and extension officers, most of the questions were closed form with a few of open form although all the questions were closed form in case of farmers. Necessary coding of data was done after collecting the data and transferred these into computers for analysis by the help of SPSS program.

\section{Problem Analysis}

A Focus Group Discussion (FGD) was held to pinpoint the farmers' problems related issues with social media usage. Twenty farmers were chosen for this reason, and they were divided into four sub-groups. A total number of 22 problems were chosen from all the subgroups, after which 10 common problems were identified and ranked by the subgroups. As a result, ten issues were discovered outside of the study area.

Among the extension officials, another FGD was made. To identify their issues in social media use, 10 officers were selected. Initially, ten problems were selected, and 5 common problems were finalized and finally classified by the extending officers.

\section{Attitude Measurement}

Respondent's attitude has been measured by constructing a 5-point Likert type scale. A 5-point scale consisting of 10 items (statements) for farmers and extension personnel on social media use was constructed for this purpose.

The response categories were given simple weightages (1 to 5) based on the items' favorability or unfavourability. The 'strongly agree' response was given a weight of 5 , while the agree, undecided, disagree, and strongly disagree responses were given weights of 4, 3, 2, and 1, respectively, for favorable (positive) statements. The reverse score was used in the case of unfavorable (negative). Similar types of attitude measurement scale were also utilized by some other researchers like, [26]-[30] in their respective research.

Individual statement score was analyzed by summation of the total given score by the respondents. There were 60 farmers and 30 extension officers as the respondents of the study. So, the individual item score could range from 60 to 300 for farmers and 30 to 150 for the extension officers. 


\section{RESUlTS AND Discussions}

\section{A. Farmers Personal Characteristics}

From the Table I it is indicated that $100 \%$ of the farmers in this study were male and majority of them $(46.7 \%)$ fell under the middle age category. Around 53.3 percent of the farmers were illiterate, with $20 \%$ having completed basic school, $20 \%$ secondary school, and only 6.7 percent having completed higher education. This demonstrates that our education system is still inadequate at the farmer level. On the basis of land categorization, the survey found that small, grouped farmers accounted for the most $(38.3 \%)$, followed by marginal grouped farmer $(31.7 \%)$. The majority of farmers (56.7 percent) rely solely on agricultural crops for their living, with 21.7 percent relying on agriculture with animal husbandry and ten percent relying on agriculture with fisheries. This suggests that a significant number of farmers do not use integrated farming. Furthermore, the bulk of farmers, 85 percent, used a button phone, while only $15 \%$ possessed a smartphone. This is due to the fact that most farmers are unaware of how to operate a smartphone.

TABLE I: DISTRIBUTION OF THE FARMERS ACCORDING TO THEIR PERSONAL INFORMATION

\begin{tabular}{|c|c|c|c|c|}
\hline Variable & Categories & Frequency & $\%$ & Mean \\
\hline \multirow{3}{*}{$\begin{array}{c}\text { Age } \\
\text { (Years) }\end{array}$} & Young $(<29$ years $)$ & 16 & 26.7 & \multirow{3}{*}{42.82} \\
\hline & $\begin{array}{c}\text { Middle ( } 30 \text { to } 52 \\
\text { years) }\end{array}$ & 28 & 46.7 & \\
\hline & Old $(>52$ years $)$ & 16 & 26.7 & \\
\hline Sex & $\begin{array}{c}\text { Male } \\
\text { Female } \\
\end{array}$ & $\begin{array}{l}60 \\
00 \\
\end{array}$ & $\begin{array}{c}100.0 \\
00.0\end{array}$ & 1.00 \\
\hline \multirow{4}{*}{$\begin{array}{c}\text { Education } \\
\text { Level (Year } \\
\text { of } \\
\text { Schooling) }\end{array}$} & Cannot read and write & 32 & 53.3 & \multirow{4}{*}{0.80} \\
\hline & Primary (1 to 5$)$ & 12 & 20.0 & \\
\hline & Secondary (6 to 10$)$ & 12 & 20.0 & \\
\hline & Higher $(>10)$ & 4 & 6.7 & \\
\hline \multirow{5}{*}{$\begin{array}{l}\text { Land } \\
\text { (Acre) }\end{array}$} & Landless $(<0.05$ acre $)$ & 7 & 11.7 & \multirow{5}{*}{2.68} \\
\hline & $\begin{array}{c}\text { Marginal (0.06 to } 0.9 \\
\text { acre) }\end{array}$ & 19 & 31.7 & \\
\hline & Small (1 to 2 acre) & 23 & 38.3 & \\
\hline & Medium ( 2 to 5 acre) & 8 & 13.3 & \\
\hline & Large ( $>5$ acre) & 3 & 5.0 & \\
\hline \multirow{6}{*}{$\begin{array}{l}\text { Income } \\
\text { Source }\end{array}$} & Agriculture & 34 & 56.7 & \multirow{6}{*}{2.58} \\
\hline & Animal Husbandry & 1 & 1.7 & \\
\hline & Fisheries & 2 & 3.3 & \\
\hline & $\begin{array}{l}\text { Agriculture }+ \\
\text { Fisheries }\end{array}$ & 6 & 10.0 & \\
\hline & $\begin{array}{c}\text { Agriculture +Animal } \\
\text { Husbandry }\end{array}$ & 13 & 21.7 & \\
\hline & $\begin{array}{c}\text { Agriculture }+ \\
\text { Fisheries + Animal } \\
\text { Husbandry }\end{array}$ & 4 & 6.7 & \\
\hline Using & Smartphone & 9 & 15.0 & \multirow{2}{*}{1.85} \\
\hline Technology & Button phone & 51 & 85.0 & \\
\hline
\end{tabular}

\section{B. Extension Agents' Personal Characteristics}

The extension officers selected for the study had homogenous personal characteristics such as education, source of revenue, use of technology etc. The candidates in Bangladesh who hold a diploma in agriculture have a specific educational criterion, therefore they all have a similar educational background. They also have a common wage structure, so there is also a minimum variation. Furthermore, they also use similar types of technology as they are similar in nature. This is why their personal data have not been collected for the study.

\section{Use of Social Media by the Farmers}

According to the data in Table II, just $11.7 \%$ of farmers used social media. The majority of farmers did not use social media because they lacked a smartphone, did not have the time to use it, and did not understand how to use it. Many of them were also averse to utilizing social media. A reduction in the cost of a smartphone and a data plan in rural areas could let farmers access agricultural extension consulting services via social media suggested by [31]. Farmers primarily used Facebook and YouTube. Due to a lack of interest, they were not followed by any agricultural channel. Approximately $8.4 \%$ of farmers spent $1-4$ hours per day on social media. The majority of farmers who used social media were mostly influenced by their neighbors. Around $11.7 \%$ of them used social media to look for agricultural information, amusement, personal reasons, and information exchange. Approximately $96.7 \%$ of farmers did not disclose any agricultural data. Due to the assumption that information is either worthless or difficult to find, the use of social media as a source of knowledge is frequently disregarded [32].

Only three of the seven farmers who used Facebook were members of various Facebook groups, while six were in contact with various Facebook pages, and only one farmer indicated that he obtained research information from Facebook. The majority of the YouTube users were enjoying songs, drama and movies in YouTube, however, 6 of them were watching agricultural videos while only 2 of them were involved with agricultural channel and they mainly watch different videos of agricultural crops, fisheries and animal husbandry.

\section{Use of Social Media by Extension Agents}

According to the data shown in Table III, 93.3 percent of extension officers use social media. The number of people who utilize social media is growing every day because they are becoming more aware of the benefits of doing so. The majority of extension officers (46.7\%) used both Facebook and YouTube, while 20\% used Facebook, YouTube, and other apps, and $16.7 \%$ primarily used the Facebook app. Around $20 \%$ of extension officers used social media for enjoyment, agricultural information, personal reasons, and information sharing.

Table III also found that 66.6 percent of extension officers had been utilizing social media for one to five years. The majority of users spent one to four hours every day on social media. Approximately 53.3 percent of extension officers spent less than one hour per day searching for agriculturerelated material. Meanwhile the majority (83.3\%) of extension officers communicated agricultural knowledge. About 33.3 percent of extension officers prefer Facebook to other social media for communicating with farmers in order to assist and benefit them. Around $80 \%$ of extension officers had agriculture-related personal Facebook pages and groups, however the majority $(73.3 \%)$ did not have an agriculturerelated YouTube channel. Because there were more farmers in our country than extension officers, 73.3 percent of extension officers believed that social media may help bridge the gap between agricultural extension officers and farmers. And eighty percent of extension officers thought it had a significant impact on agriculture. Lack of connection with farmers has long been seen as a serious flaw in extension services, and social media offers a viable solution [33]. 
TABLE II: SEVERAL FEATURES OF FARMERS' USE OF SOCIAL MEDIA

\begin{tabular}{|c|c|c|c|c|}
\hline Variable & Categories & Frequency & $\%$ & Mean \\
\hline \multirow{2}{*}{ Social media use } & Yes & 7 & 11.7 & \multirow{2}{*}{1.88} \\
\hline & No & 53 & 88.3 & \\
\hline \multirow{3}{*}{$\begin{array}{l}\text { Types of social } \\
\text { media use }\end{array}$} & Not user & 53 & 88.3 & \multirow{3}{*}{4.10} \\
\hline & Facebook \& YouTube & 5 & 8.3 & \\
\hline & Facebook \& YouTube + other & 2 & 3.3 & \\
\hline \multirow{6}{*}{ Using time } & None & 53 & 88.3 & \multirow{6}{*}{0.40} \\
\hline & $<1$ year & 1 & 1.7 & \\
\hline & 1 to 2 years & 2 & 3.3 & \\
\hline & 2 to 3 years & 1 & 1.7 & \\
\hline & 4 to 5 years & 2 & 3.3 & \\
\hline & $>5$ years & 1 & 1.7 & \\
\hline \multirow{5}{*}{ Purpose of use } & None & 53 & 88.3 & \multirow{5}{*}{0.57} \\
\hline & Entertainment & 2 & 3.3 & \\
\hline & Agricultural information + entertainment + personal & 1 & 1.7 & \\
\hline & $\begin{array}{l}\text { Agricultural information +entertainment }+ \text { sharing } \\
\text { information }\end{array}$ & 1 & 1.7 & \\
\hline & $\begin{array}{c}\begin{array}{c}\text { Agricultural information }+ \text { entertainment }+ \text { personal } \\
+ \text { sharing information }\end{array} \\
\end{array}$ & 3 & 5.0 & \\
\hline \multirow{2}{*}{$\begin{array}{l}\text { Share agriculture } \\
\text { information }\end{array}$} & Yes & 2 & 3.3 & \multirow{2}{*}{1.9} \\
\hline & No & 58 & 96.7 & \\
\hline \multirow{6}{*}{$\begin{array}{l}\text { Every day time } \\
\text { spend }\end{array}$} & None & 53 & 88.3 & \multirow{6}{*}{0.38} \\
\hline & 1 hour & 1 & 1.7 & \\
\hline & 2 hours & 1 & 1.7 & \\
\hline & 3 hours & 2 & 3.3 & \\
\hline & 4 hours & 1 & 1.7 & \\
\hline & More than 4 hours & 2 & 3.3 & \\
\hline \multirow{4}{*}{$\begin{array}{l}\text { Searching time in } \\
\text { agricultural } \\
\text { information }\end{array}$} & None & 59 & 98.3 & \\
\hline & $<1$ hour & 0 & 0 & \\
\hline & 1-2 hours & 0 & 0 & 1.05 \\
\hline & $>2$ hours & 1 & 1.7 & \\
\hline & Not user & 53 & 88.3 & \\
\hline & Own & 1 & 1.7 & \\
\hline & Neighbors & 5 & 8.3 & \\
\hline Influencing source & Local leaders & 0 & 0 & 0.7 \\
\hline & Extension workers & 0 & 0 & \\
\hline & Others & 1 & 1.7 & \\
\hline & Yes & 7 & 11.7 & \\
\hline Using facebook & No & 53 & 88.3 & 1.88 \\
\hline & None & 53 & 88.3 & \\
\hline Facehook usino & Entertainment & 1 & 1.7 & \\
\hline $\begin{array}{l}\text { Facebook using } \\
\text { purpose }\end{array}$ & $\begin{array}{l}\text { Agricultural information }+ \text { entertainment }+ \text { personal } \\
\text { purpose }\end{array}$ & 4 & 6.7 & 0.67 \\
\hline & Agricultural information + sharing info. + personal purpose & 2 & 3.3 & \\
\hline & Yes & 3 & 5.0 & \\
\hline Facebook group & No & 57 & 95.0 & 1.9 \\
\hline & None & 54 & 90.0 & \\
\hline Facehook nage & Agriculture everyday & 1 & 1.7 & 072 \\
\hline Facebook page & Krisi o jibon+ krishi shamprasaron odhidoptor & 1 & 1.7 & 0.12 \\
\hline & Krisi o jibon+ krishi shamprasaron odhidoptor+ bioscope & 4 & 6.7 & \\
\hline Getting research & Yes & 1 & 1.7 & \\
\hline information & No & 59 & 98.3 & 1.98 \\
\hline & None & 52 & 86.7 & \\
\hline & Educational and Training & 1 & 1.7 & \\
\hline & Government agricultural policies and plans & 1 & 1.7 & \\
\hline & $\begin{array}{l}\text { Educational and Training + Government agricultural } \\
\text { policies and plans }\end{array}$ & 2 & 3.3 & \\
\hline information in & $\begin{array}{c}\text { Technological information }+ \text { Education and training }+ \\
\text { Business and trade }\end{array}$ & 1 & 1.7 & 0.93 \\
\hline & $\begin{array}{c}\text { Technological information }+ \text { Education and training }+ \\
\text { Weather condition and environmental information }\end{array}$ & 2 & 3.3 & \\
\hline & $\begin{array}{l}\text { Technological info. + Education and training }+ \text { Weather } \\
\text { condition and environmental information }+ \text { govt. and agri. } \\
\text { Innovation }\end{array}$ & 1 & 1.7 & \\
\hline & Yes & 7 & 11.7 & 180 \\
\hline Using YouTube & No & 53 & 88.3 & 1.88 \\
\hline & None & 53 & 88.3 & \\
\hline YouTube using & Songs & 1 & 1.7 & 070 \\
\hline purpose & Song + dramas + movies & 1 & 1.7 & 0.70 \\
\hline & Song + dramas + movies + agri. Info & 5 & 8.3 & \\
\hline Watching & Yes & 6 & 10.0 & \\
\hline agricultural video & No & 54 & 90.0 & 1.90 \\
\hline Involve in & Yes & 2 & 3.3 & 107 \\
\hline agricultural channel & No & 58 & 96.7 & 1.97 \\
\hline & None & 54 & 90.0 & 0.58 \\
\hline
\end{tabular}




\begin{tabular}{|c|c|c|c|c|c|}
\hline Variable & Categories & & Frequency & $\%$ & Mean \\
\hline \multirow{3}{*}{$\begin{array}{l}\text { Following } \\
\text { agricultural channel }\end{array}$} & Mati O Manush" & & 2 & 3.3 & \\
\hline & Dipto Krishi ${ }^{*}+$ Krishoker mo & otha* & 3 & 5.0 & \\
\hline & Mati O Manush ${ }^{*}+$ Krishi B & $\mathrm{pe}^{*}$ & 1 & 1.7 & \\
\hline \multirow{5}{*}{$\begin{array}{l}\text { Interest in farming } \\
\text { system }\end{array}$} & \multicolumn{2}{|c|}{ None } & 54 & 90.0 & \multirow{5}{*}{0.70} \\
\hline & \multicolumn{2}{|l|}{ Fisheries } & 1 & 1.7 & \\
\hline & \multicolumn{2}{|c|}{ Agriculture farming + Fisheries } & 2 & 3.3 & \\
\hline & \multicolumn{2}{|c|}{ Agriculture farming + Fisheries + Animal husbandry } & 2 & 3.3 & \\
\hline & \multicolumn{2}{|c|}{$\begin{array}{l}\text { Agriculture farming + Animal husbandry + Integrated } \\
\text { farming system }\end{array}$} & 1 & 1.7 & \\
\hline \multicolumn{6}{|c|}{ TABLE III: SEVERAL FEATURES OF EXTENSION AGENTS USE OF SOCIAL MEDIA } \\
\hline Variable & Categories & Frequency & $\%$ & \multicolumn{2}{|r|}{ Mean } \\
\hline \multirow{2}{*}{$\begin{array}{l}\text { Social media } \\
\text { use }\end{array}$} & Yes & 28 & 93.3 & \multirow{2}{*}{\multicolumn{2}{|c|}{1.07}} \\
\hline & No & 2 & 6.7 & & \\
\hline \multirow{5}{*}{$\begin{array}{l}\text { Types of social } \\
\text { media use }\end{array}$} & None & 2 & 6.7 & \multirow{5}{*}{\multicolumn{2}{|c|}{4.03}} \\
\hline & Facebook & 5 & 16.7 & & \\
\hline & Facebook + YouTube & 14 & 46.7 & & \\
\hline & Facebook + YouTube + Others & 6 & 20.0 & & \\
\hline & $\begin{array}{c}\text { Facebook }+ \text { WhatsApp }+ \text { YouTube } \\
+ \text { Others }\end{array}$ & 3 & 10.0 & & \\
\hline \multirow{7}{*}{ Purpose of use } & None & 2 & 6.7 & & \\
\hline & Agricultural information & 6 & 20.0 & & \\
\hline & Personal purpose & 1 & 3.3 & & \\
\hline & Entertainment + Agricultural information & 1 & 3.3 & & \\
\hline & $\begin{array}{l}\text { Entertainment }+ \text { Agricultural information } \\
+ \text { Sharing information }\end{array}$ & 7 & 23.3 & & 5.97 \\
\hline & $\begin{array}{c}\text { Entertainment }+ \text { Agricultural } \\
\text { information }+ \text { Personal purpose }\end{array}$ & 7 & 23.3 & & \\
\hline & $\begin{array}{c}\text { Entertainment }+ \text { Agricultural } \\
\text { information }+ \text { Personal purpose }+ \\
\text { Sharing information }\end{array}$ & 6 & 20.0 & & \\
\hline & None & 2 & 6.7 & & \\
\hline & $<1$ year & 2 & 6.7 & & \\
\hline & $1-2$ years & 7 & 23.3 & & \\
\hline Using time & $2-3$ years & 4 & 13.3 & & 3.50 \\
\hline & $3-4$ years & 4 & 13.3 & & \\
\hline & $4-5$ years & 5 & 16.7 & & \\
\hline & $>5$ years & 6 & 20.0 & & \\
\hline & None & 2 & 6.7 & & \\
\hline & 1 hour & 14 & 46.7 & & \\
\hline $\begin{array}{l}\text { Everyday time } \\
\text { snend }\end{array}$ & 2 hours & 9 & 30.0 & & 2.70 \\
\hline & 4 hours & 1 & 3.3 & & \\
\hline & More than 4 hours & 4 & 13.3 & & \\
\hline Sharing & Yes & 25 & 83.3 & & \\
\hline $\begin{array}{l}\text { agricultural } \\
\text { information }\end{array}$ & No & 5 & 16.7 & & 1.17 \\
\hline & None & 2 & 6.7 & & \\
\hline & Facebook & 10 & 33.3 & & \\
\hline & YouTube & 2 & 6.7 & & \\
\hline & Facebook + YouTube & 9 & 30.0 & & \\
\hline Preterable & Facebook + Imo & 2 & 6.7 & & 4.03 \\
\hline & Facebook + YouTube + Imo + Others & 3 & 10.0 & & \\
\hline & $\begin{array}{c}\text { Facebook }+ \text { YouTube }+ \text { WhatsApp }+ \\
\text { Imo }+ \text { Others }\end{array}$ & 1 & 3.3 & & \\
\hline & Others & 1 & 3.3 & & \\
\hline Searching & None & 3 & 10.0 & & \\
\hline Agricultural & $<1$ hour & 16 & 53.3 & & 240 \\
\hline information in & 1-2 hours & 7 & 23.3 & & 2.40 \\
\hline social media & $>2$ hours & 4 & 13.3 & & \\
\hline Personal & Yes & 24 & 80.0 & & 120 \\
\hline Facebook page & No & 6 & 20.0 & & 1.20 \\
\hline Personal & Yes & 24 & 80.0 & & 120 \\
\hline Facebook group & No & 6 & 20.0 & & 1.20 \\
\hline Personal & Yes & 8 & 26.7 & & \\
\hline $\begin{array}{l}\text { YouTube } \\
\text { channel }\end{array}$ & No & 22 & 73.3 & & 1.73 \\
\hline Communication & Yes & 22 & 73.3 & & 127 \\
\hline gap reduce & No & 8 & 26.7 & & 1.21 \\
\hline Impact of social & Yes & 24 & 80.0 & & \\
\hline $\begin{array}{l}\text { media in } \\
\text { agriculture }\end{array}$ & No & 6 & 20.0 & & 1.20 \\
\hline
\end{tabular}




\section{E. Problems of the Farmers in Social Media Use}

There were ten major and common issues among the farmers which are mentioned in the following Fig. 1.

From the radar chart Farmers' lack of awareness has been ranked as a major cause with a score of 24 for their limited use of social media followed by illiteracy of the farmers, lack of training, high cost of internet, respectively.

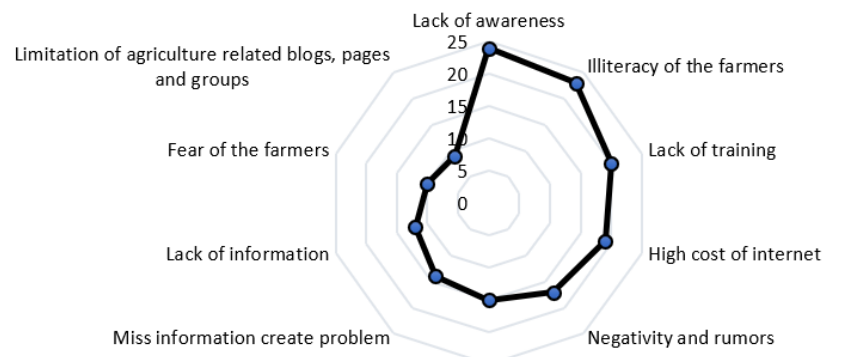

Poor internet access in rural area

Fig. 1. Determination of farmers' problems regarding social media.

\section{F. Problems of Extension Agent in Social Media Use}

There were five common issues among the extension officers which are mentioned in the following Fig. 2. From the chart expensive data pack was ranked as number one cause for their limited use of social media followed by slow internet connection and lack of training respectively. From the chart expensive data pack was ranked as number one cause for their limited use of social media followed by slow internet connection and lack of training, respectively.

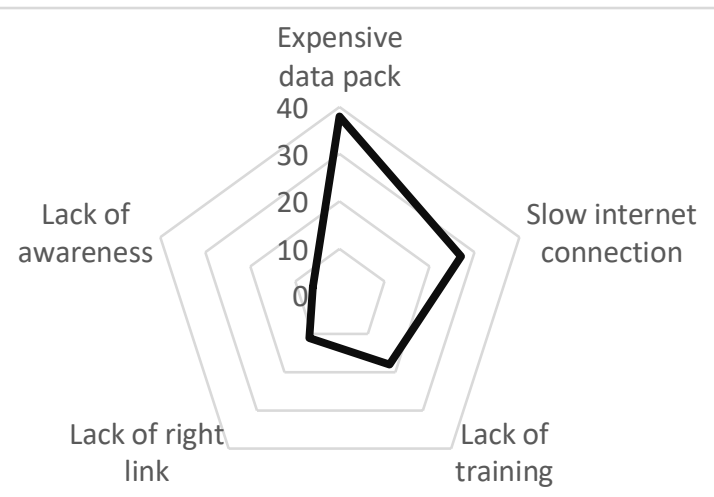

Fig. 2. Determination of extension agent's problems regarding social media.

\section{G. Farmers Attitude towards Social Media}

Attitude score of the respondents on social media use was obtained by adding together scores on all the 10 statements is present in the interview schedule. Thus, attitude score of a farmer could from 10 to 50, where 10 indicating 'very low attitude' and 50 "very high attitudes". The farmers were categorized based on their attitude scores through following statements (Table IV).

Based on computed scores the farmers were classified into least favorable, moderately favorable, and most favorable attitude. Similar categorization was also followed by [30].
TABLE IV: STATEMENT WISE SCORE OF FARMERS ATTITUDE TOWARDS SOCIAL MEDIA

\begin{tabular}{|c|c|c|}
\hline Sl. & Statements & Score \\
\hline 1 & It is necessary to know about social media & 224 \\
\hline 2 & $\begin{array}{c}\text { Social media is important for solving different } \\
\text { Agricultural problem }\end{array}$ & 235 \\
\hline 3 & Social media use increase consciousness & 186 \\
\hline 4 & $\begin{array}{l}\text { Social media is helpful in market based agricultural } \\
\text { information including market trend, price of the product, } \\
\text { stock availability etc. }\end{array}$ & 145 \\
\hline 5 & $\begin{array}{c}\text { Social media is important for getting any help from the } \\
\text { extension agent }\end{array}$ & 266 \\
\hline 6 & $\begin{array}{c}\text { Social media is important for getting any help from the } \\
\text { Government }\end{array}$ & 189 \\
\hline 7 & $\begin{array}{l}\text { Social media directly or indirectly helps to get benefit } \\
\text { through increasing yield reducing crop loss }\end{array}$ & 175 \\
\hline 8 & $\begin{array}{l}\text { Government support is not needed to enhance the use of } \\
\text { social media }\end{array}$ & 276 \\
\hline 9 & $\begin{array}{l}\text { Social media is not useful to increase the relationship } \\
\text { among the farmer }\end{array}$ & 122 \\
\hline 10 & $\begin{array}{l}\text { Social media is useful to enhance the efficiency of } \\
\text { farmer }\end{array}$ & 82 \\
\hline
\end{tabular}

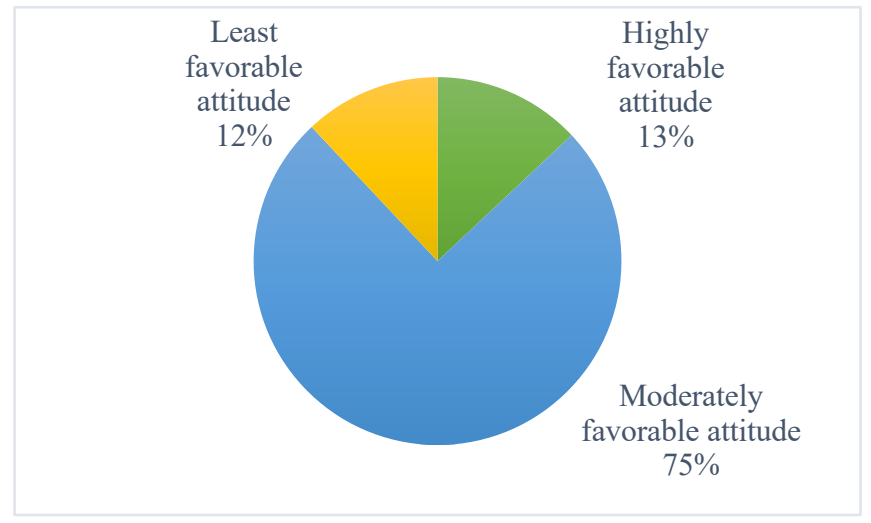

Fig. 3. Distribution of the farmers according to their attitude towards social media.

Fig. 3 indicated that majority (75\%) of the farmers showed moderately favorable attitude towards social media followed by highly favorable attitude (13.3\%) and least favorable attitude $(11.7 \%)$, respectively. Similar findings were also found in the study of [34], [35], [29]. The study area's farmers were excited about adopting social media. They believed that social media competence was essential. It could help them deal with a variety of agricultural issues by supplying marketbased agricultural data such as market trends, product prices, and stock availability, among other things. They agreed that using social media to reach out to the extension agent and the government is crucial. They insisted that improving social media usage would necessitate government assistance.

\section{H. Extension Agents' Attitude towards Social Media}

Extension personnel's attitude towards social media was measured using the following ten statements (Table V).

Based on computed scores the extension staffs were classified into least favorable, moderately favorable, and highly favorable attitude shown in the following Fig. 4.

In the Fig. 4 , it is indicated that majority $(88 \%)$ of the extension personnel had moderate to highly favorable attitude towards social media. The extension workers opined agriculture benefits from the use of social media. Rural regions' geographical isolation can be solved through online connections, which have proven to be effective in the formation of bonding capital while complementing face-to 
face networking. So, they were hopeful of utilizations of social media in agriculture bring major breakthrough.

TABLE V: STATEMENT Wise SCORE of EXTENSION AgENTS ATtitude TOWARDS SOCIAL MEDIA

\begin{tabular}{|c|c|c|}
\hline S1. & Statements & Score \\
\hline 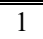 & It is easy to use different social media & 128 \\
\hline 2 & $\begin{array}{l}\text { Sharing information through social media is } \\
\text { effective }\end{array}$ & 117 \\
\hline 3 & Cost of social media is high & 108 \\
\hline 4 & $\begin{array}{l}\text { Social media strengthens linkage between } \\
\text { extension workers and farmers }\end{array}$ & 125 \\
\hline 5 & Faith in social media is relatively poor & 65 \\
\hline 6 & $\begin{array}{l}\text { Social media is effective for getting feedback } \\
\text { information }\end{array}$ & 98 \\
\hline 7 & $\begin{array}{l}\text { Only rich farmers can get the benefit of social } \\
\text { media }\end{array}$ & 114 \\
\hline 8 & Social media is useful for up-to-date information & 86 \\
\hline 9 & $\begin{array}{l}\text { Social media may be an alternative of existing } \\
\text { extension systems }\end{array}$ & 134 \\
\hline 10 & $\begin{array}{l}\text { Social media is failed to provide accurate } \\
\text { information }\end{array}$ & 54 \\
\hline
\end{tabular}

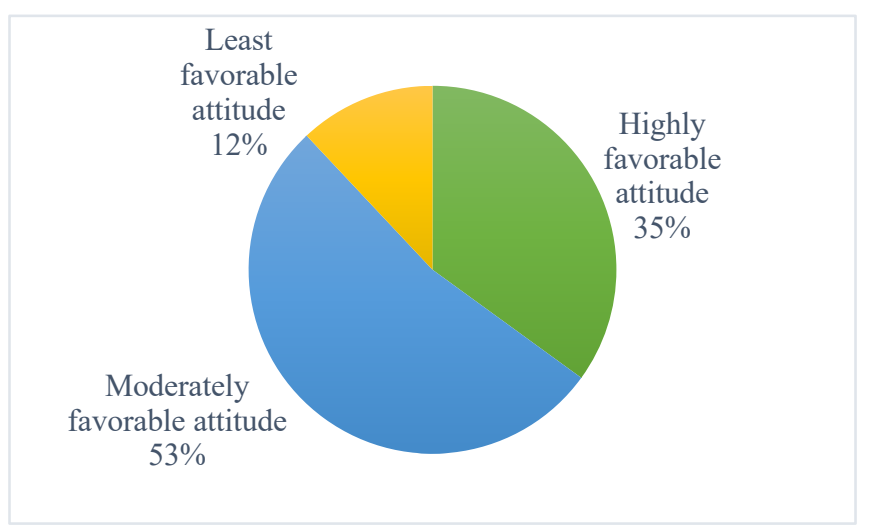

Fig. 4. Distribution of extension officers according to their attitude towards social media.

\section{CONCLUSION}

According to the findings of the study, farmers' usage of social media was unsatisfactory, and those who do use it are mostly middle-aged farmers although it was moderately utilized by extension employees. However, the results of solely using social media for agricultural purposes fell short of our expectations. For agricultural extension services to improve, farmers and extension agents need to become more engaged on social media. Both farmers and extension agents had a positive attitude toward social media to obtain agricultural information, leading to the conclusion that social media is a valuable source of agricultural knowledge that is both inexpensive and convenient. Furthermore, the majority of respondents thought that social media has advantages in agriculture. The major difficulties among farmers were determined to be a lack of understanding and illiteracy and expensive data package among the extension agents. As a result, farmers must be educated about the use of social media in agriculture, as well as the development of agriculturerelated apps. The government can also aid by providing lowcost smartphones, cheap data packs, and training centers in each union to assess farmers' usage of social media.

\section{ACKNOWLEDGMENT}

The authors would like to acknowledge EXIM Bank Agricultural University Bangladesh, especially the Department of Agricultural Extension \& Rural Development. We are also grateful to the farmers from whom data have been collected.

\section{REFERENCES}

[1] Merriam-Webster, Social Media, (2019). Retrieved from MerriamWebster:https://www.merriamwebster.com/dictionary/social $\% 20$ media.

[2] S. Kemp. (2017). Digital in 2017: Global Overview. We are social, Media Company. Retrieved from https://wearesocial.com/specialreports/ digital-in-2017globaloverview

[3] S. Stanley. (2013). Harnessing social media in Agriculture. A report for the New Zealand Nuffield farming scholarship trust. Retrieved from http://www.nuffield.org.nz/uploads/ media/S_Stanley_2013_Final_Report.pdf

[4] P. Malone, S. U. Akbar, M. Bell, and A. B. Bohn. (2013). Report on the status of ICT for agricultural extension in Bangladesh. Retrieved from https://agrilinks.org/sites/default/files /resource/files/REPORT\%20on\%20I

[5] Saiful (2013). Agricultural Extension Services in Bangladesh. https://agricultureandfarming.wordpress.com/2013/11/07/agriculturalextension-services-in Bangladesh

[6] Teagasc, "Teagasc Best Practice in Extension Services- Supporting farmer innovation" Conference Proceedings, Aviva Stadium, Lansdowne Road, Dublin 4, Ireland, 2012.

[7] A. Macken-Walsh, C. High and B. Horan, "Applying Sociology to Agricultural Extension: A Multi-Actor. Approach”, Paper presented at the XXIV European Congress for Rural Sociology, Chania, Crete, (pp. 22-25). Book of Abstacts by working group, 68, 2011.

[8] World Bank, World Development Report 2016: Digital Dividends. Washington, D.C., 2016.

[9] A. Goyal, ICT in Agriculture Sourcebook: Connecting Smallholders to Knowledge, Networks, and Institutions, World Bank, Washington D.C., 2011.

[10] C. Karthikeyan, "Impact of e-Velanmai (e-Agriculture): An ICT Enabled Agricultural Extension Model", International J. of Exten. Ed 50, (8), 24-30, 2012.

[11] A. Ayanso, and D. Moyers, The role of social media in the public sector: Opportunities and challenges, Citizen 2.0: Public and governmental interaction through Web 2.0 technologies, Hershey, PA: Information Science Reference, 1-22, 2012.

[12] B. Ibrahim, A. Aljarah and B. Ababneh, "Do social media marketing activities enhance consumer perception of brands? A meta-analytic examination," Journal of Promotion Management, 26, 544-568, 2020.

[13] E. K. Stern, Crisis management, social media, and smart devices, Application of social media in crisis management: Advanced sciences and technologies for security applications, Cham: Springer International Publising, 21-33, 2017.

[14] C. M. White, Social media, crisis communication, and emergency management: Leveraging web 2.0 technologies, Boca Raton: CRC Press, 2012.

[15] D. Andres, and J. Woodward, Social media handbook for agricultural development practitioners, Washington, DC: United States Agency for International Development (USAID), 2013.

[16] R. Saravanan, B. Schiradipta, A. Chowdhury, K. Hall, and H. H. Odame, Social media for rural advisory services (Note 15), Lindau, Switzerland: Global Forum for Rural Advisory Services (GFRAS), 2015.

[17] J. Kinsey, "Five social media tools for the extension toolbox," Journal of Extension, 48: Article 5TOT7, 2010.

[18] M. Parsons, "Social media tools for the extension toolbox", Journal of Extension, 53: Article 2TOT7, 2015.

[19] S. Cornelisse, J. Hyde, C. Raines, K. Kelley, D. Ollendyke, and J. Remcheck, "Entrepreneurial extension conducted via social media", Journal of Extension, 49: Article 6TOT1, 2011.

[20] Nielsen, Nielsen Company: "Social Networks Blogs Now Account for One in Every Four and a Half Minutes Online", 2015.

[21] Statista, "Number of social media users worldwide from 2010 to 2021," http://www.statista.com/statistics/278414/numberof-worldwidesocial-network-users.

[22] S. Jain, "30 Amazing Digital and Social Media Marketing Stats and Facts of Bangladesh -2018," Social Media Marketing Tips. Available 
at: https://www.soravjain.com/digital-marketingand-social-mediamarketing-stats-and-facts-of-bangladesh, 2019.

[23] E. Muslihat, A. Azhar, K. Kusmiyati, W. Indriatmi, "Kompetensi penyuluh pertanian dalam penyusunan rancangan usaha agribisnis padi pada BKP5K Kabupaten Bogor Provinsi Jawa Barat, ” Agriekonomika. 4(2), 132-153, 2015.

[24] R. Nasrullah, Media Sosial: Perspektif Komunikasi, Budaya, dan Sosioteknologi. Bandung (ID): Simbiosa Rekatama Media, 2017.

[25] L. Murali Krishnan, “Farmer's' M-Readiness (Mobile Readyness) indicators and mobile based agro market advisory services" Research Journal of Agricultural and Extension Studies (e-journal) 1(1): 7-13, 2017.

[26] S. Saha, S. S. Hasan, M. E. Haque and T. Ahamed, "Perception Based Assessment of Ecosystem Services of Madhupur Sal Forest in Bangladesh," European Journal of Agriculture and Food Sciences, 3(1): 39-44, 2021.

[27] S. S. Hasan, S. Saha and M. Z. Hoque, "Assessment of the Farmers' Perception on Vermicompost as Waste Management Practice and Economic Return in Some Areas of Bangladesh," European Journal of Agriculture and Food Sciences 3(3): 14-20, 2021.

[28] S. S. Hasan, M. A. Ali and M. I. Khalil, "Impact of pineapple cultivation on the increased income of pineapple growers," The Agriculturists, 8(2): 50-56, 2010.

[29] S. S. Hasan, M. Z. Turin, M. K. Ghosh and M. I. Khalil, "Assessing Agricultural Extension Professionals Opinion towards Sustainable Agriculture in Bangladesh," Asian Journal of Agricultural Extension, Economics and Sociology 17(1): 1-13, 2017.

[30] S. S. Hasan, M. K. Ghosh, M. S. Arefin, and S. Sultana, "Farmers' attitude towards using agrochemicals in rice production: A case in Laxmipur District of Bangladesh," The Agriculturists 13(2): 105, 2015.

[31] S. Bhattacharjee and R. Saravanan, "Social media: Shaping the future of agricultural extension and advisory services," GFRAS interest group on ICT4RAS discussion paper, GFRAS: Lindau, Switzerland, 2016.

[32] P. Cook, "Using new ICT tools and social media in providing advice GRDC," Update Papers, Grains and Research and Development Corporation (GRDC) Department of Primary Industries, Victoria, Australia, 2013.

[33] S. Bhattacharjee and R. Saravanan, "Social media for agricultural extension: Extension Next," Bulletin 1, MANAGE, Hyderabad, India, 2017.

[34] M. K Ghosh and S. S. Hasan, "Farmers' attitude towards sustainable agricultural practices," Bangladesh Research Publications Journal 8(4): 227-235, 2013.

[35] N. Salawat, S. S. Hasan, A. S. Khan, M. S. Rahman, M. M. Hoque and M. Moonmoon, "Study on knowledge and attitude of mushroom growers at selected Upazilas of Dhaka," Bangladesh Journal of Mushroom 7(1): 49-57, 2013. 